\title{
The Eurogroup, Power and Accountability
}

\author{
Paul Craig*
}

\begin{abstract}
This article considers the role of the Eurogroup in EU decision-making, a topic that is under-theorized, more especially given its importance in the overall EU schema. The Eurogroup's power has grown very considerably, largely because of the enhanced role that it has been accorded as a result of the financial crisis, with the result that its power no longer accords with the Treaty provisions that specify its function. The article sets out the Treaty foundations of the Eurogroup, examines its role in EU decision-making, the rationale for its increased power, and the extent to which it is politically and legally accountable.
\end{abstract}

\section{Introduction}

The Eurogroup can lay good claim to being the EU body that is least understood, which is surprising given the important role that it plays in EU decision-making. This article seeks to enhance understanding of this body. ${ }^{1}$ The discussion begins with elaboration of the Eurogroup's foundations within the Treaty. This is then followed by analysis of the ways in which it exercises political power within the EU. It exercises very considerable power over

\footnotetext{
* Professor of English Law, St John's College, Oxford. An earlier version of this paper was given at a conference in Uppsala, and I am grateful for the comments that I received on that occasion.

${ }^{1}$ See also, U. Puetter, How a Secretive Circle of Finance Ministers Share European Economic Governance (University of Manchester, European Policy Research Unit, 2006); C. Callies, 'The Governance Framework of the Eurozone and the Need for Treaty Reform', in F. Fabbrini, E. Hirsch Ballin, and H. Somersen (eds.), What Form of Government for the European Union and the Eurozone? (Hart Publishing, 2015), Chap. 3.
} 
policy and planning for states that subscribe to the euro, and is also at the centre of implementation and execution of such policy. The focus then shifts to political accountability, which includes discussion as to the rationale for the increase in the Eurogroup's power, the nature of the Eurogroup within the lexicon of political institutions and the extent to which it is politically accountable. The remainder of the article is concerned with the Eurogroup's legal accountability, which came to the fore in recent disputes before the EU courts. The courts' reasoning is set out, followed by a critique of the legal status quo.

\section{Foundations}

The Eurogroup ${ }^{2}$ took shape with the introduction of the single currency, towards the turn of the last millennium. The first informal meeting of finance ministers of the euro area countries occurred on 4 June 1998 at the Château de Senningen in Luxembourg. There is a proximate connection between the Eurogroup and the formal EU institutions. Thus the Eurogroup can hold preliminary discussions on Council decisions that apply only to the euro area Member States, and it is the Eurogroup that prepares the Euro Summit meetings and is responsible for their follow-up.

The Eurogroup is recognized in Article 137 TFEU, which provides that "arrangements for meetings between ministers of those Member States whose currency is the euro are laid down by the Protocol on the Euro Group". The preamble to Protocol 14 is framed in terms of the need to promote stronger economic growth in the EU and to develop closer coordination of economic policies within the euro area. It emphasizes the need for special provisions for enhanced dialogue between the euro area Member States, pending the euro becoming the currency of all EU Member States. Article 1 provides that euro area Ministers shall meet informally when necessary "to discuss questions related to the specific

\footnotetext{
${ }^{2}$ http://www.consilium.europa.eu/en/council-eu/eurogroup/.
} 
responsibilities they share with regard to the single currency". It specifies that the Commission shall take part in the meetings, and that the ECB should be invited. Article 2 provides for the election of a President of the Eurogroup for two and a half years, by a majority of those Member States.

The Eurogroup is composed of ministers of the euro area Member States and is a forum for discussion of shared responsibilities related to the euro. It normally meets each month, before the Economic and Financial Affairs Council (Ecofin) meeting. Meetings may, however, be held more often, as during the financial crisis. The Commissioner for Economic and Financial Affairs, Taxation and Customs, and the President of the ECB participate in the Eurogroup meetings. The Managing Director of the European Stability Mechanism (ESM) is invited to participate in the meetings, so too is the International Monetary Fund (IMF) in relation to discussion of programmes in which it is involved.

The Eurogroup President, Jeroen Dijsselbloem, has held the post since 21 January 2013 and was re-elected for a second term on 13 July 2015. He is the second President in the history of the Eurogroup, and is also Minister for Finance of the Netherlands, and Chair of the Board of Governors of the ESM. The President of the Eurogroup is a position of particular importance. ${ }^{3}$ The office is held for two and a half years, and the President's powers make the incumbent central to EU decision-making in this area. The President sets the agenda, chairs Eurogroup meetings, and draws up the long-term work programme. He is the visible face of the Eurogroup, and represents the Eurogroup in international fora, such as the G7 and IMF. The fact that the current President is also Chair of the Board of Governors of the ESM adds further to his importance.

\footnotetext{
${ }^{3}$ http://www.consilium.europa.eu/en/council-eu/eurogroup/president/role/.
} 
There is also a Eurogroup Working Group, ${ }^{4}$ which is a preparatory body composed of representatives of the euro area Member States of the Economic and Financial Committee, the European Commission and the ECB. It provides assistance to the Eurogroup and its President in preparing ministers' discussions. The Eurogroup Working Group has a President elected for two years and will normally meet each month, prior to the Eurogroup meetings.

\section{Political Power}

\section{A Policy and Planning}

The Eurogroup operates as an informal body in which the ministers discuss matters relating to their countries' common responsibilities concerning the euro. ${ }^{5}$ Its principal task is to ensure close coordination of economic policies among the euro area Member States and promote conditions for stronger economic growth.

The Eurogroup has, however, played an increasingly important role in decisionmaking since the financial crisis. The reality is that it is central to all major initiatives relating to the euro area, broadly conceived, which cover structural adjustment, macro-economic planning, negotiation with states in receipt of aid from the ESM, and aspects of banking union. The President of the Eurogroup was one of the five Presidents of the report that established the architecture for reform in the wake of the economic crisis. ${ }^{6}$

Eurogroup discussions include issues that impact the fiscal, monetary and structural policies of the euro area Member States. The Eurogroup will regularly discuss matters such

\footnotetext{
${ }^{4}$ http://www.consilium.europa.eu/en/council-eu/eurogroup/eurogroup-working-group/.

${ }^{5}$ http://www.consilium.europa.eu/en/council-eu/eurogroup/how-the-eurogroup-works/.

${ }^{6}$ H. Van Rompuy in close collaboration with J. M. Barroso, J-C. Juncker and M. Draghi, Towards a Genuine Economic and Monetary Union (2012); J-C. Juncker, in close collaboration with D. Tusk, J. Dijsselbloem, M. Draghi and M. Schultz, Completing Europe's Economic and Monetary Union (2015).
} 
as the economic outlook in the euro area; budgetary policies of the euro area Member States; the macroeconomic situation in the euro area; structural reforms that can increase growth; financial stability in the euro area; terms of financial assistance for euro area countries with severe financial difficulties; preparations for international meetings; and euro area enlargement.

The centrality of the Eurogroup to EU macro-economic planning is attested to by its important role in relation to Euro Summits. The first such meeting was held on 12 October 2008 and was a specialized meeting of the European Council for euro states. ${ }^{7}$ The Treaty on Stability, Coordination and Governance, the Fiscal Compact, formalized these arrangements, by making provision for such Euro Summits to be held at least twice per year, and more when necessary. ${ }^{8}$ They are attended by the leaders of the euro states, "to discuss questions relating to the specific responsibilities which the Contracting Parties whose currency is the euro share with regard to the single currency, other issues concerning the governance of the euro area and the rules that apply to it, and strategic orientations for the conduct of economic policies to increase convergence in the euro area". ${ }^{9}$ There is provision for attendance by non-euro area states. The President of the Euro Summit must ensure the preparation and continuity of Euro Summit meetings, in close cooperation with the Commission President. However it is the Eurogroup that is charged with the detailed preparation and follow up to the Euro Summit

\footnotetext{
${ }^{7}$ European Council, Brussels 15 and 16 October 2008, para. 3.

${ }^{8}$ There are constitutional difficulties with accepting that this could be achieved through the TSCG, but they are not relevant to the present discussion, see, P. Craig and M. Markakis, 'The Euro Area, its Regulation and Impact on Non-Euro Member States', in P. Koutrakos and J. Snell (eds.), Research Handbook on the Law of the EU's Internal Market (Edward Elgar, 2016).

${ }^{9}$ Art. 12(1) TSCG.
} 
meetings, and its President may be invited to attend such meetings. ${ }^{10}$ The reality is that the President of the Eurogroup is invited to attend.

The centrality of the Eurogroup to EU macro-economic planning is evident from its six-monthly work programme. ${ }^{11}$ Thus in the second half of 2015 the Eurogroup's priority was to improve the euro area's longer-term growth prospects. This entailed, inter alia, the optimal ways to implement structural policies that would be beneficial to the euro area, and participation in the assessment of draft budgetary plans of the euro area Member States. ${ }^{12}$ The same breadth is apparent in the work programme for the first half of 2016, which was intended to "facilitate a longer working horizon and to help ensure an optimal preparation of issues for discussion". ${ }^{13}$ The principal objectives during this six month period included: the co-ordination of Eurogroup policy responses to bolster economic growth and job creation; ensuring proper implementation of the European Semester strategy; monitoring budgetary responsibility by euro area states, including the excessive deficit procedure; reviewing the macro-financial assistance programme in Greece and Cyprus; carrying forward the initiatives on banking union; and fostering consensus within the EU so as to facilitate representation in external bodies such as the G7. ${ }^{14}$

\section{B Execution and Implementation}

\footnotetext{
${ }^{10}$ Art. 12(4) TSCG.

11 http://www.consilium.europa.eu/en/council-eu/eurogroup/work-programme/.

12 Regulation (EU) 473/2013 of the European Parliament and of the Council of 21 May 2013 on common provisions for monitoring and assessing draft budgetary plans and ensuring the correction of excessive deficit of the Member States in the euro area, OJ L140/11, of 21.5.2013, Arts. 6-7.

13 Work programme for the Eurogroup for the first half of 2016, 7 December 2015, p. 1, http://www.consilium.europa.eu/en/council-eu/eurogroup/work-programme/.

${ }^{14}$ Work programme for the Eurogroup for the first half of 2016, p. 2.
} 
Policy requires execution, plans demand implementation. The Eurogroup is central in this respect: it brokers the agreements necessary for policy to become reality; it fosters implementation through close oversight; it plays a role in ensuring that EU legislation in the financial sector is properly implemented; and it is part of the accountability mechanism in the banking union. Space precludes detailed elaboration of these four dimensions, but some flavour of each can nonetheless be conveyed. ${ }^{15}$

The Eurogroup as broker of agreements is powerfully exemplified by its role in the negotiations with Greece, more especially during the difficult days of 2015, when protracted discussions were held with the then new Tsipras government. It was the President of the Eurogroup that was centre stage during this discourse. The devil is always in the detail when it comes to securing agreement. This is readily apparent from the Eurogroup meetings held during this period. Thus in his report of the 20 February 2015 meeting the President of the Eurogroup expressed his appreciation for Greece's reform efforts over the past years, and noted its request for an extension on its loan agreement. While expressing sympathy for the plight of Greece, the President made clear that any extension was dependent on Greek compliance with the structural reforms that were conditions for the assistance. The same theme is picked up in the report of the Eurogroup on 24 February 2015, in which it considered in greater detail the reforms implemented by Greece thus far, congratulating it on what it had done, while exhorting it to further develop and broaden the list of reform measures. The tone of the President's report from the meeting on 9 March 2015 was more troubled. It stressed the importance the Eurogroup attached to Greece standing by commitments that it had undertaken in earlier meetings. More such meetings were to follow, in which the Eurogroup was central to the ongoing discussions. The reports bear testimony to

\footnotetext{
${ }^{15}$ Eurogroup meetings are available at http://www.consilium.europa.eu/en/council-eu/eurogroup/.
} 
the complexity of the financial constraints, and to the structural reforms that were the condition for the grant of the assistance. ${ }^{16}$

The Eurogroup also plays a second role in relation to oversight and implementation of the agreements. This is exemplified by the Eurogroup report from 9 May 2016, which dealt specifically with the Greek programme. The Eurogroup considered the policy package agreed in August 2015; an additional contingency mechanism; and discussed what might be done about debt and sustainability. There was considerable discussion about implementation of the 2015 package, in particular the difficult measures relating to pension reform, personal income tax reform and additional fiscal parametric measures. The Eurogroup also began to explore options concerning restructuring debt, in order to facilitate Greek access to the markets. It discussed the way forward, with sequenced proposals for the short, medium and long term.

The Eurogroup makes an important contribution in the third sense adumbrated above, by monitoring application of EU Treaty provisions and legislation. The Commission and ECB are lead players in this respect, but the Eurogroup is also significant. Thus the meeting of 9 March 2015 spent considerable time on structural reforms to particular economic areas, such as the services sector. The Eurogroup noted the possible gains for the EU economy, such that reducing restrictions to the level of the five best performing countries would bring gains of $2.4 \%$ of GDP at EU level. The discussion also embraced the political challenges of reforming the service sector, including tackling vested interests and reducing the burden of excessive regulation. A repeat item on the Eurogroup work programme concerns compliance by euro area states with the EU macro-economic budgetary criteria. Thus the Eurogroup meeting of 9 March 2015 considered, in the light of Commission analysis, the risks that seven Member States might not comply with the Stability and Growth Pact in 2015. More recently, the Eurogroup meeting on 24 May 2016 considered the report from the ECB and the

\footnotetext{
${ }^{16}$ http://www.consilium.europa.eu/en/press/press-releases/2015/08/14-jd-remarks/.
} 
Commission concerning the post-programme situation in Spain, and discussed Greece's implementation of the ESM economic adjustment programme. ${ }^{17}$

The Eurogroup also has a fourth role in relation to implementation, being part of the accountability mechanism in the banking sphere. The remedial measures for the financial crisis included provisions to increase centralized control over banking and credit institutions, which took effect through the Single Supervisory Mechanism, SSM, and the Single Resolution Mechanism, SRM. ${ }^{18}$ The ECB, together with its Supervisory Board, are the principal decision-makers in the SSM regime, while the Single Resolution Board, an EU agency, the ECB and Commission play this role in the SRM regime. The relevance of this lies in the Eurogroup's power concerning accountability for the decisions made.

The SSM Regulation provides that the ECB is accountable to the European Parliament and to the Council for its implementation, ${ }^{19}$ while the SRM Regulation provides that the SRB shall be accountable to the European Parliament, the Council, and the Commission. ${ }^{20}$ The ECB and the SRB must submit reports concerning performance of their tasks to the European Parliament. ${ }^{21}$ The SSM Regulation provides in addition that the ECB should present its report to the Eurogroup in the presence of any representatives from non-

\footnotetext{
${ }^{17}$ http://www.consilium.europa.eu/en/meetings/eurogroup/2016/05/24/.

${ }^{18}$ Council Regulation (EU) 1024/2013 conferring specific tasks on the European Central Bank concerning policies relating to the prudential supervision of credit institutions, OJ L287/63, of 15.10.2013, (SSM Regulation); Regulation (EU) 806/2014 of the European Parliament and of the Council establishing uniform rules and a uniform procedure for the resolution of credit institutions and certain investment firms in the framework of a Single Resolution Mechanism and a Single Resolution Fund and amending Regulation (EU) No 1093/2010, OJ L225/1, of 15.7.2014 (SRM Regulation).

${ }^{19}$ Regulation 1024/2013, Art. 20(1).

${ }^{20}$ Regulation 806/2014, Art. 45(1).

${ }^{21}$ Regulation 1024/2013, Arts. 20(2)-(3); Regulation 806/2014 Art. 45(2)-(3).
} 
Euro area participating Member States, ${ }^{22}$ whereas the SRM Regulation specifies that the SRB must present its report to the Council. ${ }^{23}$

The SSM Regulation further provides for the Eurogroup to exercise some accountability/supervisory role in relation to the primary decision-makers in this area. Thus the annual report must be sent by the ECB to the Eurogroup, as well as the EP, Council and Commission; ${ }^{24}$ the Chair of the Supervisory Board of the ECB must present that report in public to the EP and the Eurogroup, in the presence of any participating non-euro states; ${ }^{25}$ the Chair of the ECB Supervisory Board may, at the request of the Eurogroup, be heard on the execution of its supervisory tasks by the Eurogroup in the presence of representatives from any participating Member States whose currency is not the euro; ${ }^{26}$ and the ECB shall reply to questions put to it by the EP, or by the Eurogroup. ${ }^{27}$ The parallel provisions in the SRM Regulation provide for the Chair of the SRB to be heard on the execution of its tasks by the Council, and to answer questions from the EP and Council. ${ }^{28}$ It is clear therefore that the Eurogroup has some formal executive powers to hold the primary decision-makers to account within the SSM regime.

\section{Political Accountability}

\section{A Political Accountability: Four Dimensions}

\footnotetext{
${ }^{22}$ Regulation 1024/2013, Art. 20(3)

${ }^{23}$ Regulation 806/2014, Art. 45(3).

${ }^{24}$ Regulation 1024/2013, Art. 20(2).

${ }^{25}$ Ibid, Art. 20(3).

${ }^{26}$ Ibid, Art. 20(4).

${ }^{27}$ Ibid, Art. 20(6).

${ }^{28}$ Regulation 806/2014, Art. 45.
} 
There is a significant literature on political accountability within the EU. ${ }^{29}$ The ensuing discussion will be informed by Mark Bovens' conception of accountability, which is a relationship between an actor and a forum, in which the actor has an obligation to explain and to justify his or her conduct, the forum can pose questions and pass judgement, and the actor may face consequences. ${ }^{30}$ This conception must, however, be seen against the backdrop of four factors or dimensions that frame accountability discourse and help to explain diversity of views.

First, there are normative assumptions against which the accountability of a particular institution is judged. Thus EU accountability may be viewed against the premise that the allocation of institutional power should ensure that a body with democratic credentials exercises control over the direction of EU policy for which it can be held accountable to the

${ }^{29}$ See, e.g., A. Arnull and D. Wincott (eds.), Accountability and Legitimacy in the European Union (Oxford University Press, 2002); C. Harlow, Accountability in the European Union (Oxford University Press, 2002); R. Mulgan, Holding Power to Account: Accountability in Modern Democracies (Palgrave Macmillan, 2003); E. Fisher, 'The European Union in the Age of Accountability', (2004) 24 Oxford Journal of Legal Studies 495; V. Bogdanor, Legitimacy, Accountability and Democracy in the European Union (Federal Trust, 2007); M. Bovens, 'Analysing and Assessing Accountability: A Conceptual Framework', (2007) 13 European Law Journal 447; D. Curtin, Executive Power of the European Union. Law, Practices and the Living Constitution (Oxford University Press, 2009); S. Gustavsson, C. Karlsson and T. Persson (eds.), The Illusion of Accountability in the European Union (Routledge, 2009); M. Bovens, D. Curtin \& P. 't Hart, 'Towards a More Accountable EU: Retrospective and Roadmap', ACELG 2010-4; M. Bovens, 'Two Concepts of Accountability: Accountability as a Virtue and as a Mechanism (2010) 33 West European Politics 946; M. Bovens, D. Curtin, and P. 't Hart (eds), The Real World of EU Accountability: What Deficit? (Oxford University Press, 2010); M. Busuioc, European Agencies: Law and Practices of Accountability (Oxford University Press, 2013); P. Craig, 'Accountability', in A. Arnull and D. Chalmers (eds.), The Oxford Handbook of European Union Law (Oxford University Press, 2015), Chap. 17.

${ }^{30}$ M. Bovens ‘Analysing and Assessing Accountability’ (2007) 13 European Law Journal 447, 450. 
electorate through the democratic process. Political accountability is therefore dependent on locating an institution within the framework of institutional actors, and it is predicated on assumptions as to the nature of the accountability to which an institution should be subject. Thus, we naturally think in different ways about the accountability of executive and legislative institutions.

Secondly, the normative dimension is then tested through evaluation of the positive rules enshrined in the constituent Treaties and regulations made thereunder. The object is to decide whether these rules enable the institutions to perform their assigned role as indicated by the normative frame, and to criticize the system if this is not possible. This entails identification of the relevant rules in order to determine whether, for example, they attribute power to institutions that possess democratic credentials, the supposition being that the principal accountability mechanism is democratic accountability through the vote.

The third factor or dimension is empirical. The inquiry focuses on whether the positive legal rules do what the legal text suggests, or whether the modus operandi of a particular institution reveals that the real world disposition of power is very different from that suggested by the black letter legal rules, with the consequence that assumptions as to whether the normative dimension of accountability is working as it should are thereby undermined. Thus our vision of agency accountability may be predicated on certain hypotheses as to how the decision-making process therein works, which may be undermined if they are falsified by empirical revelation of the true workings of power within an agency.

The fourth and final factor is temporal, in the sense that change is an endemic feature of all dispositions of institutional power, whether at the national, international or transnational level. Powers are carefully crafted, only for the real world to intrude, rendering the configuration of power unrecognizable to those who framed the constituent document. We can attempt to insulate institutions through various devices, most notably constitutions or 
the equivalent thereto. The constitutional identification of a particular body as, for example, the legislature helps to preserve institutional integrity, by ensuring that its imprimatur is, in some foundational sense, required for the legitimacy of measures labelled as legislation. However, the efficacy of such safeguards depends, inter alia, on the degree of constitutional specificity. Thus most constitutions are pretty vague concerning the locus and power of the executive.

The reality is that many differences of view concerning EU accountability turn on disagreement about one of these four factors. There is significant divergence of view at the normative level as to the framework against which EU accountability should be judged. There can be real dispute as to what the positive rules prescribe, which can shape different conclusions as to whether the normative vision is properly reflected in those rules. There are differences yet again at the empirical level, as to whether the legal rules, given their natural textual interpretation, capture the reality of how the institutions operate in practice, with consequential implications for assessment of accountability. Temporal change can, moreover, impact radically on the powers possessed by a particular institution, with consequential implications for the suitability and efficacy of accountability mechanisms.

\section{$B$ The Eurogroup: Institutional Change and Rationale}

The problems of accountability are exacerbated when, as with the Eurogroup, the particular body does not readily fall within the traditional triadic lexicon of political power. These difficulties become more acute when its powers have changed, such that there is an absence of fit between the constitutional provisions and practical reality. This is quintessentially so in relation to the Eurogroup, which is not even an EU institution in the technical sense of that term. The framers of the Lisbon Treaty carefully crafted the powers of the principal institutions, after much deliberation. The Eurogroup was accorded formal recognition, but the 
salient Treaty provisions are relatively exiguous, this bearing testimony to the largely informal, discursive nature of its perceived role.

The ink had barely dried on the Lisbon Treaty when the shockwaves of the financial crisis were felt within the EU. This was the principal rationale for the increase in the Eurogroup's power. The crisis created the need for an institution that could orchestrate the response of the euro-area Member States. The Eurogroup was perfectly situated to undertake this role. The story as it unfolded is, however, more interesting, and nuanced. The crisis that enveloped some euro area Member States required drastic measures, very significant financial aid and stringent conditionality. ${ }^{31}$ The recipient states desperately needed the assistance, but chafed nonetheless at the conditions that were attached. The execution of this package was never going to be easy. The political reality was that it could only be done by an institution populated by state representatives; the legal reality was that this had to be so, given that much of the funding came from the ESM, which was not formally part of the EU. The Eurogroup was perfectly positioned to take on the role in both regards, given more especially that the President of the Eurogroup was Chair of the ESM Board of Governors.

The inter-relationship with the traditional EU institutions was, moreover, nicely poised, with advantages to all institutional players. The Eurogroup could draw on empirical

\footnotetext{
31 There is a very large literature, see for example, M. Ruffert, 'The European Debt Crisis and European Union Law' (2011) 48 Common Market Law Review 1777; E. Chiti and P. Teixeira, 'The Constitutional Implications of the European Responses to the Financial and Public Debt Crises' (2013) 50 Common Market Law Review 683; M. Adams, F. Fabbrini and P. Larouche (eds.), The Constitutionalization of European Budgetary Constraints (Hart, 2014); K. Tuori, The Eurozone Crisis, A Constitutional Analysis (Cambridge University Press, 2014); F. Fabbrini, E. Hirsch Ballin, and H. Somersen (eds.), What Form of Government for the European Union and the Eurozone? (Hart Publishing, 2015); A. Hinarejos Parga, The Euro Area Crisis in Constitutional Perspective (Oxford University Press, 2015); F. Fabbrini, Economic Governance in Europe, Comparative Paradoxes, Constitutional Challenges (Oxford University Press, 2016).
} 
analysis from the Commission and ECB of the kind that it could not readily undertake itself; the Commission and ECB benefited from having a body composed of state representatives taking the institutional lead and consequential "heat" in difficult negotiations with states in receipt of assistance. The enhanced role of the Eurogroup thus resulted from the need for an institution that sat on the cusp of the political and the technocratic, being able to "sell" the results to euro states in a way that a principally technocratic body could not, while being taken seriously in technocratic terms in ways that a purely political body would not.

\section{The Eurogroup: The Difficulties of Securing Political Accountability}

While the growth in the Eurogroup's power is explicable for the preceding reasons this still leaves open how we should classify this body, and to whom it is accountable. It is instructive to return to Mark Bovens' conception of accountability, which is a relationship between an actor and a forum, in which the actor has an obligation to explain and to justify his or her conduct, the forum can pose questions and pass judgement, and the actor may face consequences. ${ }^{32}$

The Eurogroup is not in formal terms a configuration of the Council, nor is it an agent of the Commission or ECB. It is in reality an executive body sui generis, which partakes in certain respects the attributes of a specialist Council formation and in certain respects those of a specialist arm of the European Council. This very duality is one of the Eurogroup's institutional strengths, but it renders the demarcation of clear lines of accountability more difficult. Its principal political accountability runs to the European Council, as attested to by its role in preparing Euro Area Summits and having the responsibility for ensuring that the recommendations from such meetings are followed up. The reality is however, as seen above,

\footnotetext{
${ }^{32}$ M. Bovens 'Analysing and Assessing Accountability' (2007) 13 European Law Journal 447, 450.
} 
that the Eurogroup has considerable power in shaping macro-economic policy broadly conceived for euro-area states. The recommendations that emanate from the European Council will often be at a relatively abstract level, and it will be the Eurogroup that imbues them with greater policy specificity.

This does not preclude the Eurogroup being held to account in the European Council for the more detailed policy initiatives that the Eurogroup embraces when fulfilling European Council policy recommendations. The Eurogroup can, in Mark Bovens' terms, have an obligation to explain and to justify its conduct, the European Council can pose questions and pass judgement, and the Eurogroup may face consequences. The reality is that this is more difficult to achieve where the criteria against which the Eurogroup is being judged are relatively abstract recommendations from the European Council; where it is intended that these should be fleshed out by the Eurogroup; where all institutional players are mindful of the difficult political and economic determinations that have to be made; and where evaluation of success or failure may be difficult, and may not be apparent for some considerable time.

The difficulties of securing political accountability are equally apparent in relation to the other aspect of the Eurogroup's work, which relates to the implementation and execution of policy with respect to a particular state. It has considerable decisional autonomy over such matters, more especially when it comes to the detailed negotiations with states of the kind that were charted in the earlier part of the article. Political accountability thus exists, but is "thin". The problems in this respect are exacerbated because there is scant legal accountability, an issue to which we now turn.

\section{Legal Accountability}


The Eurogroup's legal accountability does not accord with its political power. Mallis is the key case decided initially by the General Court, ${ }^{33}$ this decision being upheld by the CJEU. ${ }^{34}$

\section{A Mallis: The Facts}

The action arose from the Cypriot banking crisis in 2012, in which certain banks became insolvent. Cyprus believed that they should be recapitalized and applied to the President of the Eurogroup for financial assistance from the EFSF, or the ESM. The Eurogroup responded positively in June 2012, indicating that the assistance would be forthcoming pursuant to a memorandum of understanding (MoU) to be negotiated between the Commission, together with the European Central Bank (ECB) and the International Monetary Fund (IMF), and Cyprus. The draft MoU was agreed in March 2013, and included certain adjustment measures including a tax on bank deposits. The agreement was welcomed by the Eurogroup, which confirmed that grant of financial assistance to safeguard financial stability in Cyprus and the euro area was, in principle, warranted.

On 18 March 2013, the President of the Eurogroup stated that the tax on bank deposits, together with the financial assistance, would be used to restore the viability of the Cypriot banking system, but that small depositors should be treated differently from large depositors, such that deposits of less than EUR 100, 000 would be fully secured. Cyprus duly enacted a law to restructure the debts and liabilities of the two major banks, the Bank of Cyprus and Laïki, on 22 March 2013, subject to an exception whereby deposits of less than

\footnotetext{
${ }^{33}$ Case T-327/13, Konstantinos Mallis and Elli Konstantinou Mali v European Commission and European Central Bank, ECLI:EU:T:2014:909.

${ }^{34}$ Cases C-105-109/15), Konstantinos Mallis and others v European Commission and European Central Bank, ECLI:EU:C:2016:702.
} 
EUR 100,000 were immune from such measures. In April 2013, the ESM Board of Governors granted support to Cyprus, and approved the draft MoU on 26 April 2013.

The applicants were depositors with Laïki and claimed to have lost all their deposits, apart from EUR 100,000. Their action rested on a "contested statement" made by the Eurogroup on 25 March 2013, which established the scheme for restructuring the financial sector. This provided for Laïki to be split into a good bank and a bad bank, the latter being run down over time, while the former would be folded into the Bank of Cyprus. The Cypriot government effectuated this on 25 March 2013, through decrees enacted pursuant to the law passed three days earlier. Certain of Laïki's assets, including deposits of less than EUR 100, 000, were transferred to the Bank of Cyprus, but deposits of more than EUR 100, 000 remained with Laiki, pending its liquidation.

\section{B Mallis: The General Court}

The applicants sought to challenge the "contested statement" of the Eurogroup, and render it actionable before the General Court. They contended that the contested statement should be regarded as a joint decision of the Eurogroup with the ECB and the Commission, which was brought into effect by the Cypriot government decrees; in the alternative, they asked the General Court to declare that the contested statement constituted a joint decision of the ECB and/or of the Commission; in the further alternative they argued that there was a joint decision of the ECB and/or the Commission, which was adopted through the Eurogroup.

The legal action was, however, brought against the ECB and the Commission, not against the Eurogroup. The GC therefore had to consider whether the contested statement could be imputed to the Commission and the ECB. This required the GC to analyze the nature of the Eurogroup and its relationship to the Commission and the ECB, with regard to 
the contested statement. The GC duly considered Article 137 TFEU, and Protocol 14 and reached three conclusions. ${ }^{35}$

First, the Eurogroup was a forum for discussion between representatives of the Member States whose currency was the euro. It was not a decision-making body. While the Eurogroup had an institutional structure to facilitate exchange of views between euro area states, it was not subsumed within the Commission or the ECB. Secondly, although there was provision for the Commission and the ECB to take part in Eurogroup meetings, the latter remained an informal meeting of the ministers of the Member States concerned. Thirdly, the Eurogroup did not receive any delegation of powers from the Commission or the ECB; nor could those institutions exercise review powers over the Eurogroup, issue it with recommendations or give it binding instructions. The Eurogroup was not therefore under the control of the Commission or the ECB, or its agent. It followed that the "contested statement" could not be imputed to the Commission or ECB. The action was therefore directed at the wrong defendants, insofar as it was brought against the Commission and the ECB.

The GC made clear that the applicants would have fared no better had they brought the claim against the Eurogroup, because only measures that produced binding legal effects by bringing about a distinct change in the applicants' legal position could be annulled under Article 263 TFEU. $^{36}$ The GC acknowledged that in order to determine whether an act produced such binding legal effects, it was necessary to look to its substance. The reasoning was however circular, with the GC concluding that it was important "to bear in mind that the Eurogroup cannot be regarded as a decision-making body", and that the "provisions governing its operation do not empower it to adopt legally binding measures", with the

\footnotetext{
${ }^{35}$ Case T-327/13, Mallis, ECLI: EU:T:2014:909, paras. 41-44, 53.

${ }^{36} \mathrm{Ibid}$, paras. 51-54.
} 
consequence that a statement made by the Eurogroup cannot "therefore be regarded as a measure intended to produce legal effects with respect to third parties". 37

\section{Mallis: Advocate General Wathelet}

The applicants appealed to the CJEU, and Advocate General Wathelet delivered his opinion in April 2016. ${ }^{38}$ His conceptual starting point determined what was to follow: the Eurogroup was not mentioned in Article 263(1) TFEU, nor was it one of the seven EU institutions listed in Article 13(1) TEU, with the consequence that its acts could be subject to annulment only if it could be regarded as a configuration of the Council, or as a body, office or agency of the Union. $^{39}$

He acknowledged that there were points of contact between the Eurogroup and the Council, but concluded that the former was not a configuration of the latter. This was because it was not listed as a Council configuration; it did not include all EU Member States; and because their respective functions were different, with those of the Council being broader than those of the Eurogroup. ${ }^{40}$

He also concluded that the Eurogroup was not an EU office, body or agency. The Advocate General acknowledged that Article 263 TFEU had been amended to ensure that no act was immune from judicial scrutiny. He nonetheless held that the Eurogroup could not be considered such a body, because it did not have legal personality. ${ }^{41}$ There was, said the AG,

\footnotetext{
${ }^{37}$ Ibid, para. 53.

38 Cases C-105-109/15, Konstantinos Mallis and others $v$ European Commission and ECB), ECLI: EU:C:2016:294.

${ }^{39} \mathrm{Ibid}$, para. 54.

${ }^{40} \mathrm{Ibid}$, para. 61.

${ }^{41}$ Ibid, para. 63.
} 
nothing to suggest that the authors of the Lisbon treaty intended to waive that requirement, and whenever the TFEU Treaty made Article 263 TFEU applicable without requiring legal personality, it expressly named the relevant institution, such as the European Council or the Committee of the Regions. ${ }^{42}$

Advocate General Wathelet dismissed the contention that the absence of review pursuant to Article 263 was problematic in terms of the principle of effective judicial protection, stating that this would only be so if the Eurogroup had power to adopt legally binding acts with respect to third parties. He, however, echoed the General Court, holding that the Eurogroup was merely a forum for discussion, not a decision-making body. ${ }^{43}$

\section{Mallis: The CJEU}

The CJEU judgment upheld the GC's decision and largely followed its reasoning. It can be summarized as follows.

First, the CJEU denied that the Eurogroup's contested statement concerning the way in which the Cypriot banks should be restructured could be regarded as a decision of the Commission and ECB. These institutions participated in the ESM, and had specific powers under the ESM Statute. Those powers were, however, limited and did not provide any basis for concluding that the Commission and ECB were the joint authors of the contested statement. $^{44}$

Secondly, the CJEU followed the GC and Advocate General and denied that the contested statement of the Eurogroup was susceptible to challenge in an annulment action. In reaching this conclusion the CJEU emphasized the wording of Protocol 14, to the effect that

\footnotetext{
${ }^{42}$ Ibid, para. 64.

${ }^{43} \mathrm{Ibid}$, para. 66.

${ }^{44}$ Cases C-105-109/15, Mallis, ECLI:EU:C:2016:702, paras. 53-60.
} 
the Eurogroup operated "informally", and the fact that it could not be considered to be a configuration of the Council, nor could it be classified as an EU body, office or agency of the within the meaning of Article 263 TFEU. ${ }^{45}$

\section{E Ledra Advertising: Damages}

While claimants have been unsuccessful in annulment actions against the Eurogroup, the CJEU held in Ledra Advertising that an action for damages under Article 340 TFEU could in principle be brought against the Commission and ECB for losses suffered as a result of recapitalization of the Cypriot banks. ${ }^{46}$

The CJEU held that unlawful conduct linked to adoption of a Memorandum of Understanding on behalf of the ESM could be raised against the Commission and the ECB in an action under Article 340 TFEU. ${ }^{47}$ The claimants nonetheless failed to satisfy the Court that there had been a sufficiently serious breach of a rule of law intended to confer rights on individuals. They contended that the Commission had not ensured that the Memorandum of Understanding complied with Article 17(1) of the EU Charter of Rights, which protected the right to property. The CJEU confirmed that the Charter was applicable to the EU institutions when they acted pursuant to the ESM. ${ }^{48}$ However, it held that the right to property was not absolute and that it could be limited on grounds of public interest, provided that the limitations did not constitute a disproportionate and intolerable interference, which impaired the very substance of the right guaranteed. The CJEU concluded that the Memorandum of

\footnotetext{
${ }^{45}$ Ibid, para. 61.

${ }^{46}$ Cases C-8/15 P to C-10/15 P, Ledra Advertising Ltd and Others v European Commission and European Central Bank, ECLI:EU:C:2016:701.

${ }^{47}$ Ibid, para. 55.

${ }^{48} \mathrm{Ibid}$, para. 67.
} 
Understanding was designed to secure the stability of the euro area monetary system and that the measures contained therein were a proportionate limitation on property rights. ${ }^{49}$

\section{Legal Accountability: A Critique}

\section{A Legal Form and Political Reality}

The reasoning of the GC, Advocate General and CJEU reveals the gap between legal form and substantive political reality. It belies the centrality of the Eurogroup to the decisionmaking process, and its relative autonomy within the EU decision-making scheme. It is illustrative of a more general problem with aspects of EU decision-making, which is the disjunction between power and responsibility. It is not clear whether the applicants should have succeeded in an annulment action, since the substantive issues were never aired. The judicial denial that the "contested statement" could be attributed to the ECB and Commission, coupled with the denial that this statement by the Eurogroup could be regarded as giving rise to binding legal effects for third parties, meant that the judicial doors to an annulment action were kept firmly shut. The factual background to the case was complex, but this should not hide the core issue. The Eurogroup was central to the deal that was struck with Cyprus. It brokered the deal and it set the core terms, which were embodied in the "contested statement". It was these very terms that the applicants contended were the cause of its serious losses. The terms may have been defensible, but we cannot know, since the Court's reasoning obviated the need for any substantive defence.

The GC, Advocate General and CJEU were on defensible ground in concluding that the "contested statement" could not be imputed to the ECB and Commission. ${ }^{50}$ The

\footnotetext{
${ }^{49}$ Ibid, paras. 71-76.

${ }^{50}$ Cases C-105-109/15, Mallis, ECLI: EU:C:2016:294, para. 108.
} 
alternative claim, viz that the Eurogroup made a decision with binding legal effects on third parties was far more contestable. The rejection of this argument was predicated on a formalistic view of the Eurogroup and its place within the EU institutional architecture, which bears little relation to reality.

This is regrettable more especially because the political reality was glimpsed, most notably by the Advocate General. Thus, having intoned formal orthodoxy to the effect that the Eurogroup was merely a forum for exchange of ideas between euro area Member States, with no formal legal powers, the Advocate General then peered behind the institutional corporate veil to perceive the reality that lay beneath.

He acknowledged that the language of the "contested statement" was not "entirely consistent" ${ }^{\prime 51}$ with the idea that the Eurogroup was merely an informal meeting of the ministers of the euro area Member States to discuss issues of shared interest concerning the single currency. He accepted that the "contested statement" was framed so as to announce that it was the Eurogroup that had come to an agreement with the Cypriot authorities concerning the macroeconomic adjustment programme, it being then for the ECB and Commission merely to set this down formally in a MoU. ${ }^{52} \mathrm{He}$ recognized that the "contested statement" established the key terms of the deal on which financial relief would be given to the two Cypriot banks, including the split of Laiiki into the good and the bad bank, the fact that only bank deposits up to EUR 100000 would be secured, the tax on other deposits and the folding of the good bank into the Bank of Cyprus. ${ }^{53}$ The peremptory force of these terms were further attested to by the timing of the events as they unfolded in 2013, with the Cypriot

\footnotetext{
${ }^{51}$ Ibid, para. 126.

${ }^{52}$ Ibid, para. 127.

${ }^{53}$ Ibid, para. 128.
} 
government bringing them into effect through the two decrees enacted in late March 2013.

The harsh glare of reality was nonetheless brushed aside, the Advocate General stating that, ${ }^{54}$

It is true that that sequence of events shows that the Euro Group clearly carries considerable political weight and that the Member States feel bound by the agreements concluded within that forum. However, this is not sufficient to support the view that the contested statement produced binding legal effects with respect to third parties within the meaning of the Court's case-law.

The Advocate General therefore concurred with the General Court in concluding that the measures decided on by the Eurogroup could not be read in isolation. They should be "read in their proper context, from which it is clear that the contested statement is purely informative in nature". 55

The political and institutional reality is surely to the contrary. The "contested statement" was not purely informative; it was determinative of the terms on which assistance would be granted. This was more especially so, given the institutional linkage between the Eurogroup and the decision-making regime under the European Stability Mechanism, which was to provide the funding. The Chairperson of the ESM Board of Governors is, in principle, the President of the Eurogroup, ${ }^{56}$ and the proximate institutional connection was noted by the Advocate General. ${ }^{57}$

It was therefore no surprise that the Cypriot authorities approached the President of the Eurogroup when they sought assistance, nor is it any surprise that the assistance when given was structured in accord with the terms of the "contested statement". This followed the logic in Article 13(1) ESM, whereby a Member State must address a request for stability support to the Chairperson of the Board of Governors, who then entrusts the Commission with assessing it, in liaison with the ECB. It is the ESM Board of Governors that decides to

\footnotetext{
${ }^{54}$ Ibid, para. 132.

${ }^{55}$ Ibid, para. 133.

${ }^{56}$ Art. 5(2) ESM.

${ }^{57}$ Cases C-105-109/15, Mallis, ECLI: EU:C:2016:294, para. 71.
} 
grant stability support to the requesting Member State on the basis of the latter's request and the assessment carried out by the Commission and the ECB. ${ }^{58}$ It is for the Commission and ECB to negotiate the $\mathrm{MoU}$ with the requesting state, ${ }^{59}$ which includes the conditionality terms attached to the assistance, but it is for the ESM Board of Governors to define the economic policy conditionality attached to the financial assistance granted to the Member State. ${ }^{60}$ In this instance all roads lead back to the Eurogroup, which was in pole position to structure the resultant deal and its terms.

\section{B Legal Form and Twin Legal Realities}

It might be argued by way of response that the reasoning of the GC, Advocate General and CJEU were defensible because it is necessary to distinguish the role of the Eurogroup and its President in relation to the ESM, from its role more generally under the Lisbon Treaty. Thus on this view the fact that its actions might be creative of legal effect under the ESM, did not mean that they could be so regarded under the Lisbon Treaty and hence were not susceptible to an annulment action under Article 263 TFEU. This response is therefore premised on what might be termed twin legal realities, these being respectively the Eurogroup's power under the ESM and under the Lisbon Treaty, each of which is treated as hermetically sealed insofar as legal accountability is concerned. The fact that the Eurogroup might wield legally dispositive power under the ESM means that the applicant must seek whatever form of legal redress is available through that Treaty. This is regarded as formally distinct from its powers under the Lisbon Treaty, which are then subject to the legal accountability regime contained therein, subject to proof of the normal requirements for such actions, viz, that it would have

\footnotetext{
${ }^{58}$ Art. 13(2) ESM.

${ }^{59}$ Art. 13(3) ESM.

${ }^{60}$ Art. 5(6)(g) ESM.
} 
to be shown that the Eurogroup operating within the Lisbon Treaty made decisions that had binding legal effect for third parties.

Advocates of this view might seek legal support from Pringle, where the CJEU reiterated the holding from previous case law that Member States are entitled, in areas which do not fall under the exclusive competence of the Union, to entrust tasks to the institutions, outside the framework of the EU, such as coordinating collective action undertaken by the Member States or managing financial assistance. ${ }^{61}$ It then added the caveat that this was subject to the proviso that "those tasks do not alter the essential character of the powers conferred on those institutions by the EU and FEU Treaties", ${ }^{2}$ drawing this principle from case law concerning international agreements made by the EU. ${ }^{63}$ It might be argued that this line of argument applies even more forcefully here, given that the body that operates within the EU, the Eurogroup, is not formally the same as that within the ESM, this being the Board of Governors, headed contingently, but not necessarily, by the President of the Eurogroup. There are a number of responses to this line of argument.

First, I have argued at length elsewhere that while the ruling in Pringle is generally to be supported, the legal statements therein concerning the power of EU institutions to act

\footnotetext{
${ }^{61}$ Case C-370/12, Pringle v Government of Ireland, Ireland and the Attorney General, ECLI: EU:C:2012:756, para. 158.

${ }^{62}$ Ibid, para. 158.

63 Opinion 1/92, Draft agreement between the Community, on the one hand, and the countries of the European Free Trade Association, on the other, relating to the creation of the European Economic Area [1992] ECR I2821, paras. 32, 41; Opinion 1/00, Proposed agreement between the European Community and non-Member States on the establishment of a European Common Aviation Area [2002] ECR I-3493, para. 20; Opinion 1/09, Draft agreement - Creation of a unified patent litigation system - European and Community Patents Court Compatibility of the draft agreement with the Treaties [2011] ECR I-1137, para. 75.
} 
outside the Lisbon Treaty, subject to the conditions specified by the CJEU, are problematic for a plethora of procedural, substantive and normative reasons. ${ }^{64}$

Secondly, the force of these arguments is not diminished merely because the body that operates in the EU is the Eurogroup, while that which wields power under the ESM is the Board of Governors. The latter is formally composed of a representative from each euro area Member State, and this is so for good reason: these are the states that are directly affected by fluctuations in the value of the euro; they are the parties that might claim assistance; and they fund the scheme. It is chaired by the President of the Eurogroup, and has been from its very inception. The identity between the membership of the Eurogroup and that of the Board of Governors is not therefore fortuitous. It is hard-wired into the system.

Thirdly, it is by no means self-evident that the criteria laid down in Pringle would be met here, since it is arguable that the tasks exercised pursuant to the ESM alter the essential character of the powers conferred on the Eurogroup by the Lisbon Treaty. The meaning of this condition is fraught with difficulty, ${ }^{65}$ but the tension arises from the insistence that the Eurogroup does not have power to make decisions with binding legal effect under the Lisbon Treaty, whereas the President of the Eurogroup and Board of Governors can make a binding agreement pursuant to the ESM. It might be contended that this does not matter because the Eurogroup should be seen as distinct from its President plus the ESM Board of Governors, thereby obviating any difficulty created by the Pringle condition. This however proves too much. It would mean that the Pringle condition concerning not altering the essential character of the powers of an institution under the Lisbon Treaty could be circumvented, or rendered otiose, by simply changing its name when it acts outside the Lisbon Treaty.

\footnotetext{
${ }^{64}$ P. Craig, 'Pringle and Use of EU Institutions Outside the EU Legal Framework: Foundations, Procedure and Substance', (2013) 9 EuConst 263.

${ }^{65}$ Ibid, pp. 277-280.
} 


\section{Legal Form and Effective Legal Protection}

Advocate General Wathelet noted at the outset of his Opinion the importance of this case from the perspective of effective judicial protection. ${ }^{66} \mathrm{He}$ was undoubtedly right in this respect. Pringle $e^{67}$ and Gauweiler ${ }^{68}$ dealt with important issues concerning the meaning of economic and monetary union, and its implications for the competence of the EU and the Member States. This still leaves open a plethora of issues concerning legal accountability in circumstances where assistance has been provided. The legal position is as follows.

First, applicants who seek to challenge the conditions on which financial assistance has been given pursuant to the ESM cannot challenge this via an annulment action under Article 263 TFEU. They will not generally be able to pursue a claim against the Commission or ECB since the Eurogroup will not be regarded as its agent, nor can the Eurogroup's statements be imputed to the Commission or ECB. There might be conceivable factual circumstances where an action could be brought against the Commission and the ECB, in relation to, for example, errors concerning their assessment of the financial situation in a particular country, and its impact on the stability of the euro, when exercising their power under the ESM Treaty. ${ }^{69}$ The imposition of the conditionality terms is, however, a matter for the Board of Governors, and the Mallis case reveals the difficulties of rendering the Eurogroup accountable under Article 263 TFEU.

Second, it will be difficult for an applicant to rely on the Charter. Pringle is authority that the Charter does not bind the Member States within the context of the ESM: the EU did

\footnotetext{
${ }^{66}$ Cases C-105-109/15, Mallis, ECLI:EU:C:2016:294, para. 53.

${ }^{67}$ Case C-370/12, Pringle, ECLI:EU:C:2012:756.

${ }^{68}$ Case C-62/14, Peter Gauweiler and others v Deutsche Bundestag, ECLI: EU:C:2015:400.

${ }^{69}$ Art. 13 ESM.
} 
not have specific competence to create a stability mechanism, and therefore Member States were not implementing EU law when creating the ESM, and hence did not fall within Article 51(1) of the Charter. ${ }^{70}$ This leaves open the issue as to whether the EU institutions can be bound by the Charter in relation to their actions under the ESM or some other such treaty. Advocate-General Kokott stated that an EU institution was bound by the full extent of EU law, including the Charter, ${ }^{71}$ and this has been affirmed in Ledra Advertising. ${ }^{72}$ There will, nonetheless, be formidable difficulties in making a Charter claim against EU institutions, even assuming they are bound by the Charter. This is because the decision that gives rise to the Charter claim may not formally be made by the EU institution, ${ }^{73}$ even though it may have substantial influence over it, or the decision may be shared with Member States that are not bound by the Charter. It would have to be decided whether the Eurogroup in the guise of the ESM Board of Governors would be bound by the Charter. The applicability of the Charter is central to those claims that the terms on which assistance has been given infringe social rights guaranteed by the Charter, since the austerity measures demanded of states impact severely on the provision of social welfare.

Thirdly, this leaves for consideration whether there is any other route whereby effective judicial protection can be secured, given that the ESM is not formally part of the EU legal order. ${ }^{74}$ The ESM states that the Board of Governors shall decide a dispute arising

\footnotetext{
${ }^{70}$ Case C-370/12, Pringle, ECLI:EU:C:2012:756, paras. 178-180.

${ }^{71}$ Case C-370/12, Pringle v Government of Ireland, Ireland and the Attorney General, ECLI:EU:C:2012:675, para. 176.

${ }^{72}$ Cases C-8/15 P to C-10/15P, Ledra Advertising Ltd and Others $v$ European Commission and European Central Bank, ECLI:EU:C:2016:701, para. 67.

${ }^{73}$ Case C-370/12, Pringle, ECLI:EU:C:2012:756, para. 161.

${ }^{74}$ Cases C-105-109/15, Mallis, ECLI:EU:C:2016:294, para. 53; Case C-370/12, Pringle, ECLI:EU:C:2012:756, para. 180 .
} 
between an ESM Member and the ESM, or between ESM Members, in connection with the interpretation and application of the ESM Treaty. If an ESM Member contests this, the dispute shall be submitted to the CJEU under Article 273 TFEU, and its decision is binding on the parties to the case. ${ }^{75}$ This is, however, only available to ESM members that are dissatisfied with the interpretation or application of the ESM Treaty, and will not avail claimants such as those in the Mallis case, who wish to contest the legality of the terms on which the assistance was granted. For such applicants there is not much by way of judicial protection, nor can it be regarded as effective.

Fourthly, there may be a small glimmer of legal light through indirect challenge to a Council decision that embodies the MoU. This is common practice, the rationale being doubt as to whether the MoU itself is legally binding ${ }^{76}$ with some national courts regarding them merely as containing the policy programme necessary to gain financial assistance. ${ }^{77}$ For Advocate General Wathelet, the Council decisions addressed to a Member State support the view that national measures adopted pursuant to commitments entered into by a Member State vis-à-vis the ESM "constitute an implementation of EU law even though the MoU does not constitute an act of EU law, provided, however, that those measures are reproduced in the Council decision adopted after the MoU has been signed". ${ }^{78} \mathrm{He}$ however followed the General Court, ${ }^{79}$ whose decisions revealed the difficulty for applicants in proving that the Council decisions were of direct concern for the purposes of Article 263 TFEU. ${ }^{80}$ While the

\footnotetext{
${ }^{75}$ Arts. 32(2)-(3) ESM.

${ }^{76}$ Cases C-105-109/15, Mallis, ECLI:EU:C:2016:294, paras. 83-85.

${ }^{77}$ Ibid, para. 87 .

${ }^{78}$ Ibid, para. 89.

${ }^{79}$ Case T-541/10, ADEDY and Others v Council, ECLI:EU:T:2012:626, para. 87; Case T-215/11, ADEDY and Others v Council, ECLI:EU:T:2012:627, para. 99.

${ }^{80}$ Cases C-105-109/15, Mallis, ECLI:EU:C:2016:294, para. 90.
} 
Advocate General therefore rejected the possibility of any direct action, he countenanced the possibility of indirect challenge via Article 267 TFEU, his reasoning being as follows: Article 13(3) ESM required that measures contained in the MoU must "be fully consistent" with EU law; insofar as those measures were reproduced in Council decisions, Member States were required by Article 19(1) TEU to provide "remedies sufficient to ensure effective legal protection" enabling national courts to refer to the CJEU questions for a preliminary ruling on the validity of those decisions and, consequently, the validity of the macroeconomic adjustment programme at issue. ${ }^{81}$

Fifthly, this conceptualization of indirect challenge as the means of securing judicial protection is predicated on the assumption that the Council has competence to make the decisions that replicate the MoUs. The argument presented by the Advocate General is, however, dangerously akin to legal bootstrapping: if the ESM is not part of the EU legal order national measures adopted pursuant to commitments entered into by a Member State vis-à-vis the ESM cannot constitute implementation of EU law; and if the MoU does not constitute an act of EU law, it cannot become so by being reproduced in a Council decision adopted after the MoU has been signed. The reality is, however, that EU competence to make the Council decisions is grounded in Article 126 and Article 136(1) TFEU, whereby the Council is authorized to decide whether a state has an excessive deficit, and to adopt specific measures for euro countries. It is then legally possible for the Council to include provisions in the enacted decisions that replicate some provisions in the MoU deal struck by the state under the ESM Treaty. ${ }^{82}$

\footnotetext{
${ }^{81}$ Ibid, para. 91.

${ }^{82}$ See, e.g., Council Decision 2013/236/EU of 25 April 2013 addressed to Cyprus on specific measures to restore financial stability and sustainable growth, OJ L141/32, of 25.4.2013, Art. 2(6)(d); Council Decision 2010/320/EU of 10 May 2010 addressed to Greece with a view to reinforcing and deepening fiscal surveillance
} 
Finally, we should not lose sight of the issue that is central to the current inquiry, which is the effectiveness of judicial protection for aggrieved individuals. The short answer is that there is not much by way of judicial protection and it is not very effective.

Applicants who seek direct actions via Article 263 TFEU face the barriers adumbrated above. If the applicants manage to convince the GC that the Eurogroup's acts have legally binding effect they will still face the normal hurdles of proving direct and individual concern. The GC's decision in $A D E D Y$ is a timely reminder of the difficulty of surmounting the direct concern barrier. ${ }^{83}$ The applicants were trade unionists representing civil servants, who challenged detailed instructions to the Greek state as to how it should reduce debt, which included provisions such as reduction of the Easter, summer and Christmas bonuses and allowances paid to civil servants with the aim of saving EUR 1500 million for a full year. The GC's response was that the Council decision did not specify the precise categories of civil servants affected, with the consequence that the Greek government therefore had discretion in this respect, and thus the applicants failed to show direct concern. The reality was that the Greek government would have to implement cuts across the board, and that it would face claims of discrimination if the burden was placed differentially on certain categories of civil servants without objective justification. The GC's reasoning denying direct concern is dangerously reductionist and renders Article 263 TFEU a dead letter, since any choice as to manner of implementation left to the state, however theoretical, will preclude a finding of direct concern.

Applicants will therefore have to seek redress in an indirect action via Article 267 TFEU. In $A D E D Y$ the GC, having found the direct action to be inadmissible, repeated the and giving notice to Greece to take measures for the deficit reduction judged necessary to remedy the situation of excessive deficit, OJ L145/6, of 10.5.2010.

${ }^{83}$ Case T-541/10, ADEDY, ECLI:EU:T:2012:626, paras. 69-88. 
mantra that the EU legal order has a complete set of remedies and that the applicants could have recourse to an indirect action via Article 267 TFEU ${ }^{84}$ The difficulties with this mantra are well known, such that there is no need to repeat them here. ${ }^{85}$ Suffice it to say that these difficulties will be especially pronounced in the present context. If the applicants are seeking to challenge the terms on which ESM assistance has been given then this will only be possible before a national court if there is a Council decision that incorporates the terms of the MoU in the manner set out above. The applicants will then face the uphill struggle of convincing a national court that they have a plausible case that a particular clause in a macroeconomic adjustment plan is tainted by some illegality so as to warrant a reference to the CJEU. This is not impossible, but it will assuredly be very difficult.

\section{Conclusion}

This article has sought to shed light on the role played by the Eurogroup within the EU political and legal order. In political terms, there is no doubting its centrality to decisionmaking in relation to EMU broadly conceived, as attested to by the high profile of its President, who is key to much that occurs in this area, both within the EU, and when the EU engages with other players on the world stage. The growth in the Eurogroup's power is a classic instance of institutional evolution, whereby a body originally conceived to have a more limited role came to occupy a far more prominent position, outstripping in the process the constitutional vestments with which it was garbed, as judged by the Treaty provisions that deal with it. In legal terms, the difficulty of securing relief where the Eurogroup is concerned is evident from the preceding analysis. It is important moreover when considering the

\footnotetext{
${ }^{84} \mathrm{Ibid}$, paras. 89-95.

${ }^{85}$ P. Craig and G. de Búrca, EU Law, Text, Cases and Materials (Oxford University Press, $6^{\text {th }}$ ed, 2015), Chap. 14.
} 
complex thicket of legal reasoning to stand back from the detail and realize something very simple and important: when action is taken at EU level "someone" did it. Conditionality terms do not fall from the sky, and the terms that shaped the facts of the Mallis case were specified by the Eurogroup. It is not an agent of the Commission or the ECB. It should be subject to legal liability in its own right, thereby ensuring a central tenet of the rule of law. 